\title{
Natalitet etničkih skupina u Hrvatskoj od 1998. do 2008.
}

DOI: $10.11567 /$ met.29.1.2

UDK: 314.3:323.11](497.5)"1998/2008"

Prethodno priopćenje

Primljeno: 20.3.2013.

Prihvaćeno: 4.6.2013.

\section{Dario Pavić}

Odjel za sociologiju, Hrvatski studiji Sveučilišta u Zagrebu, Zagreb

dpavic@hrstud.hr

\section{SAŽETAK}

Pripadnost etničkoj skupini može utjecati na socioekonomski položaj i natalitet (rodnost) pojedinca. Tako žene manjinskih etničkih skupina najčešće imaju relativno visoki natalitet, češće su samohrane majke, slabije su obrazovane i općenito slabijega socioekonomskog statusa. Iako postoje brojna međunarodna istraživanja koja su potvrdila razlike $\mathrm{u}$ natalitetu etničkih skupina, odnos narodnosti i nataliteta u $\mathrm{Hr}-$ vatskoj gotovo da i nije istraživan. Stoga se u ovom istraživanju analizirala stopa nataliteta etničkih skupina u Republici Hrvatskoj i povezanost narodnosti majke sa socioekonomskim varijablama: dob pri rađanju djeteta, obrazovanje, ekonomska aktivnost, bračnost i red rođenja djeteta. Upotrijebljeni su podaci o rođenjima iz obrazaca DEM-1 za godine od 1998. do 2008. te službeni podaci popisa stanovništva iz 2001. Utvrđena je povezanost narodnosti majke i svih socioekonomskih varijabli, iako je ona malena. Utvrđene su i značajne razlike u natalitetu etničkih skupina. Žene albanske, bošnjačke, romske i ostalih narodnosti, a donekle i žene srpske narodnosti imaju nepovoljniji socioekonomski položaj, a visoki natalitet imaju Romkinje i Albanke. Ipak, zbog metodoloških poteškoća te načina vođenja vitalne statistike nije moguće utvrditi jasnu vezu pripadnosti etničkoj skupini i nataliteta. Uvrštavanjem varijable narodnost i prikazom socioekonomskih varijabli prema narodnosti majke u službenim statističkim publikacijama, znatno bi se olakšala istraživanja te omogućila bolja i učinkovitija demografska i socijalna politika.

KLJUČNE RIJEČI: natalitet, etničnost, etničke skupine, Hrvatska

\section{UVOD}

Pripadnost određenoj etničkoj skupini može utjecati na ekonomski, socijalni i demografski status pojedinca, pogotovo ako je etnička skupina ujedno i nacionalna manjina. Tako je u Velikoj Britaniji fertilitet nacionalnih manjina na početku bio visok, da bi se u prvome desetljeću 21. stoljeća približio fertilitetu dominante etničke grupe, iako su neke manjine zadržale visoke stope fertiliteta (Coleman i Dubuc, 2010). Bjelkinje su u većoj mjeri radile na 
određeno vrijeme i najčešće su bile bez djece, dok su žene karipskog i afričkog podrijetla najčešće bile samohrane majke (Lindley, Dale i Dex, 2004). U Sjedinjenim Američkim Državama odgoda rađanja karakteristična je za visokoobrazovane bjelkinje, dok je u mnogo manjoj mjeri izražena među manje obrazovanim ženama i onima afričkog podrijetla (Yang i Morgan, 2003).

U zemljama kontinentalne Europe također postoje razlike u fertilitetu između etničkih skupina. Tako su u Francuskoj pripadnici naroda iz zemalja Magreba imali više stope fertiliteta, iako se posljednjih godina ta stopa smanjila (Penn i Lambert, 2002). U Njemačkoj je prisutan sličan trend; najviše stope fertiliteta u usporedbi s etničkim Nijemcima imali su Turci, a nakon njih pripadnici narodâ iz bivše Jugoslavije (Penn i Lambert, 2002). Zanimljivo je i da su neke etničke skupine, poput Portugalaca u Francuskoj i Turaka u Njemačkoj, izrazile stav o manjoj poželjnoj veličini obitelji te da je vjeroispovijest bila značajan čimbenik fertiliteta, neovisno o etničkoj pripadnosti. Muslimani i kršćani preferiraju veće obitelji nego vjerski neopredijeljeni (Penn i Lambert, 2002).

Uzroci i objašnjenja diferencijalnog fertiliteta između etničkih skupina brojni su i različiti, od bioloških preko psiholoških i ekonomskih do kulturnih. Forste i Tienda (1996) iznijeli su njihov sustavni pregled, uputili na njihove manjkavosti i iznijeli moguće nove teorijske pravce koji bolje objašnjavaju zamijećene pojave. U tzv. prvu generaciju objašnjenja razlika u fertilitetu među etničkim skupinama ubrajaju tri hipoteze: hipotezu socijalnih karakteristika, hipotezu statusa manjinske grupe i kulturnu hipotezu. Prema hipotezi socijalnih karakteristika, diferencijalni fertilitet između etničkih skupina funkcija je ponajprije obrazovnih i ekonomskih karakteristika majki i/ili očeva, dok hipoteza statusa manjinske grupe objašnjava niži fertilitet nekih etničkih grupa supresijom fertiliteta (odgoda rađanja, manji broj djece i dr.) zbog želje za socijalnom mobilnošću prema gore. Kulturna hipoteza naglašava kulturne vrijednosti manjinskih populacija, prije svega kod objašnjenja želje za većom obitelji. Iako te hipoteze objašnjavaju mnoge istraživane situacije, Forste i Tienda upozoravaju na važnost složenijeg međudjelovanja bioloških čimbenika (npr. dob kada se javlja prva menstruacija), okoline zajednice (segregacija, siromaštvo), utjecaja medija, obiteljske strukture, angažiranosti starijih članova obitelji (bake) i percepcije životnih ciljeva. Tim teorijskim okvirom objašnjavaju dotad »stršeće« pojave fertiliteta ponajprije meksičkih i drugih hispanoameričkih, a potom i skupina afričkog podrijetla u SAD-u (Forste i Tienda, 1996).

Istraživanja fertiliteta, nataliteta i drugih demografskih varijabli etničkih skupina u Republici Hrvatskoj iznimno su rijetka. Glavni je razlog nedostu- 
pnost etničke diferencijacije događaja vitalne statistike $u$ službenim publikacijama Državnog zavoda za statistiku. Podaci o vitalnim događajima za pojedinu etničku ili narodnosnu skupinu ne navode se u godišnjim izvješćima DZS-a kao ni u publikacijama popisa stanovništva. Navode se rođenja prema prostornom rasporedu, redu rođenja, starosti majke, obrazovanju i aktivnosti majke i dr., no ne i prema narodnosnoj pripadnosti (usp. Prirodno kretanje stanovništva..., 2009). Zbog takva stanja istraživači mogu povezivati etnički status s demografskim varijablama uglavnom kroz istraživanja na reprezentativnim uzorcima stanovništva Hrvatske.

Ipak, postoje istraživanja koja tematiziraju etničke razlike u socioekonomskom statusu koje, prema navedenim teorijama, mogu utjecati na različite obrasce nataliteta etničkih skupina. Ona se uglavnom koncentriraju na pojedine etničke skupine i usporedbu njihova statusa sa statusom dominantnog stanovništva hrvatske narodnosti. Tako Šućur (2009) tvrdi da je udio Srba u Hrvatskoj koji žive u kućanstvima s niskim prihodom otprilike dva i pol puta veći nego odgovarajući udio Hrvata, dok je on kod ostalih nacionalnih manjina u usporedbi s Hrvatima veći za pedesetak posto. Te razlike posljedica su različite strukture navedenih etničkih grupa prema dobi, tipu kućanstva, obrazovanju, broju zaposlenih i regionalnoj pripadnosti. Kod romske nacionalne manjine vidljiva je prostorna segregacija na razini naselja (za Rome u Međimurju), gdje Romi žive u etnički homogenim dijelovima naselja, odvojeni od lokalnog stanovništva (Šlezak, 2009). Za romsku nacionalnu manjinu postoji studija fertiliteta i mortaliteta, iako ograničena na naselje Kuršanec u Međimurju (Šlezak, 2010). To istraživanje pokazuje trend smanjenja visokih stopa fertiliteta u Roma, relativno niski mortalitet, ali i relativno visoki mortalitet dojenčadi.

Neka istraživanja narodnosti za razdoblje socijalističke Jugoslavije pokazala su zanimljive etničke obrasce demografskih procesa. Tako je od 1962. do 1989., unatoč popularnoj predodžbi o množini etnički miješanih brakova u tadašnjoj Jugoslaviji, bila izrazita unutaretnička homogenost sklopljenih brakova (Botev, 1994). U tadašnjoj SR Hrvatskoj sve etničke skupine davale su prednost odabiru bračnih partnera iste narodnosti, što je bilo najizraženije kod Albanaca i Mađara.

Etnička struktura Hrvatske rezultat je stoljetnih procesa i rasprava o njoj izlazi iz okvira ovog istraživanja. Ipak, bitno je napomenuti najvažnije promjene etničke strukture, posebice od polovine 20. stoljeća do sada. Prema popisima stanovništva, udio Hrvata na prostoru današnje Republike Hrvatske raste od 79,5\% (1953.) do 90,4\% (2011.), a prema najnovijem popisu broj Hrvata u RH iznosi 3.874.321. Na taj broj, uz nepovoljnu rodnost i emi- 
graciju, najviše su utjecali gubici u Drugome svjetskom ratu i Domovinskom ratu. Pretpostavlja se da su ukupni demografski gubici Hrvata u dva svjetska rata iznosili 340.000 (Žerjavić, 1993, prema Akrap, 2008). U Domovinskom ratu poginulo je 8147 hrvatskih branitelja i 6605 civila, a nestalo je 1218 hrvatskih branitelja i civila (Živić i Pokos, 2004). Na broj Hrvata utjecala je i dinamika prognanog i izbjeglog stanovništva, pogotovo doseljenih Hrvata iz BiH i Srbije. Prema podacima za 1998., oko 150.000 ljudi trajno se doselilo iz BiH i tadašnje Savezne Republike Jugoslavije u Hrvatsku, većinom Hrvata (Gelo, 1999).

Na broj srpskog stanovništva u Hrvatskoj prema Popisu stanovništva iz 2001. godine (186.633, 4,4\% ukupnog stanovništva) najviše su utjecale ratne operacije u Drugome svjetskom ratu i Domovinskom ratu te povratak dijela srpskog stanovništva u Hrvatsku. Ukupni demografski gubici Srba u Hrvatskoj tijekom Drugoga svjetskog rata iznosili su 201.000 (Žerjavić, 1993, prema Akrap, 2008). Poginulih i nestalih Srba iz Hrvatske tijekom Domovinskog rata bilo je 6222, dok je broj izbjeglica iz RH u BiH i SiCG 1997. iznosio 376.999 (uglavnom Srbi), da bi se 2003. smanjio na 237.160 (Živić i Pokos, 2004). Udio Bošnjaka, Talijana, Albanaca, Roma, Mađara, Slovenaca i Čeha manji je od jedan posto ukupnog stanovništva Hrvatske, za svaku od tih skupina posebno. Te etničke skupine karakterizira uglavnom prostorna homogenost: Talijani žive većinom u Istarskoj i Primorsko-goranskoj županiji, Mađari u Osječko-baranjskoj, Česi u Bjelovarsko-bilogorskoj te Romi u Međimurskoj županiji i Gradu Zagrebu. Važno je napomenuti da je broj Talijana u Hrvatskoj najvećim dijelom rezultat njihova egzodusa nakon Drugoga svjetskog rata, tako da se njihov broj iz 1948., oko 85.000, smanjio na malo više od 17.000 u 2011. (Klemenčič, 2006). Isto tako, 1910. u istočnoj Hrvatskoj živjelo je oko 80.000 Nijemaca, da bi, što zbog raspada Austro-Ugarske Monarhije, što zbog progona nakon Drugoga svjetskog rata, njihov broj 1948. spao na malo manje od 8000 (Živić, 1998).

Cilj istraživanja jest utvrditi postojanje razlika u natalitetu (rodnosti) i socioekonomskim karakteristikama između etničkih skupina u Republici Hrvatskoj na temelju podataka o rođenjima od 1998. do 2008. Postojanje takvih razlika pokazalo bi različitu sociodemografsku strukturu pojedinih etničkih skupina i upozorilo na različite društvene procese prema njima. 


\section{MATERIJAL I METODE}

Podaci upotrijebljeni $\mathrm{u}$ istraživanju najvećim su dijelom iz obrazaca DEM-1 kojima se evidentira svako rođenje u Republici Hrvatskoj. Za godine od 1998. do 2008. dostavio ih je Državni zavod za statistiku prema ugovoru sklopljenom s Hrvatskim studijima Sveučilišta u Zagrebu bez identifikatora koji bi mogli otkriti identitet majke i oca. Ukupno su bila dostupna 468.783 podatka o pojedinačnim rođenjima, od kojih su 466.656 bili živorođeni, a 2127 mrtvorođeni. Varijable od interesa pri ovoj analizi bile su narodnost majke i oca, red rođenja djeteta, dob majke i oca, obrazovanje majke i oca, ekonomska aktivnost majke i oca, je li dijete rođeno u braku te koji je to majci brak po redu. Za potrebe analize sve varijable pretvorene su u kategoričke intervalne ili nominalne varijable.

Za varijablu narodnost majke i oca odabrano je devet najbrojnijih etničkih skupina u Republici Hrvatskoj prema popisu stanovništva iz 2001., dok su ostale narodnosti zbrojene $\mathrm{u}$ kategoriju »ostali«. Najbrojnije su narodnosti u Hrvatskoj hrvatska, albanska, bošnjačka, češka, mađarska, romska, slovenska, srpska i talijanska. Bošnjačkoj narodnosnoj skupini pridruženi su i oni koji su se izjasnili kao Muslimani. Ostale varijable pretvorene su u nominalne ili ordinalne varijable $s$ tri kategorije.

Razdoblje od 1998. do 2008. odabrano je iz nekoliko razloga. Prvo, 1998. završena je mirna reintegracija Hrvatskog Podunavlja u teritorijalno-administrativni sustav Republike Hrvatske, pa se vitalna statistika počela bilježiti za cijeli teritorij i sve stanovništvo Hrvatske. Drugo, iste godine uveden je novi način vođenja statistike prema ukupnome prisutnom broju stanovnika. Podaci do 1998. prikupljani su prema načelu de iure, tako da su u vitalnu statistiku Republike Hrvatske ulazile i osobe koje su duže boravile u inozemstvu, zbog čega podaci prije 1998. nisu izravno usporedivi s novijim podacima. Gornja granica istraživanog intervala, 2008. godina, izabrana je jer je nakon nje nastupila međunarodna gospodarska kriza, koja je rezultirala ekonomskom recesijom, padom proizvodnje, emigracijom i većom nezaposlenošću. Te ekonomske neprilike vjerojatno su se odrazile na rodnost u Republici Hrvatskoj, pa bi se kombinacijom tih podataka s onima prije ekonomske krize dobili iskrivljeni rezultati o etničkoj pripadnosti kao mogućoj odrednici nataliteta.

Razlike u dobi majke i oca, u njihovoj aktivnosti i obrazovanju, kao i u ostalim navedenim varijablama između narodnosnih skupina u Republici Hrvatskoj testirane su hi-kvadrat testovima. Takav test proveden je za narodnost i svaku pojedinu varijablu, gdje se narodnost tretirala kao neza- 
visna varijabla. Značajni rezultat pojedinoga hi-kvadrat testa upućuje na razlike $u$ određenoj socioekonomskoj varijabli između osoba različite narodnosti. Radi lakše interpretacije u tablicama su navedeni standardizirani reziduali, gdje odstupanje više od 1,96 u bilo kojem smjeru sugerira značajno odstupanje stvarnih vrijednosti od očekivanih $(\mathrm{p}=0,05)$. Procijenjena je $\mathrm{i}$ povezanost dviju varijabli Cramerovim V-testom. Narodnost kao nezavisna varijabla definirana je narodnošću majke rođenog djeteta. Za neke analize postotak majki unutar svake narodnosne kategorije prikazan je grafički.

Natalitet pojedine etničke skupine iskazan je prosječnom godišnjom stopom nataliteta za navedeno jedanaestogodišnje razdoblje. Ukupni broj stanovnika pojedine etničke skupine u Republici Hrvatskoj od 1998. do 2008. određen je po broju stanovnika odgovarajuće etničke skupine prema popisu stanovništva iz 2001. Stoga je prosječna godišnja stopa nataliteta za pojedinu etničku skupinu u istraživanom razdoblju izračunata prema formuli:

$$
N_{i}=\frac{B_{i}}{P_{i(2001)} \cdot 11} \cdot 1000
$$

gdje je $B_{i}$ broj rođenih od majke narodnosti $i$ u jedanaestogodišnjem razdoblju, a $P_{i}$ ukupni broj stanovnika određene narodnosti $i$ prema popisu stanovništva iz 2001. Uobičajena je praksa da se referentnim ukupnim brojem stanovnika smatra onaj iz godina na sredini promatranog intervala. Iako 2001. godina nije na sredini istraživanog intervala, ipak je upotrijebljena zbog jednostavnosti i dostupnosti. 


\section{REZULTATI}

U Republici Hrvatskoj od 1998. do 2008. ukupni je broj živorođene djece 466.656. U tablici 1 vidljiv je vrlo veliki raspon stopa nataliteta za svaku od narodnosti majke. Najveći natalitet imaju majke romske narodnosti, dok je natalitet majki slovenske nacionalnosti najniži.

Tablica 1. Prosječne godišnje stope nataliteta i ukupni broj živorođenih prema narodnosti majke u Republici Hrvatskoj od 1998. do 2008.

Table 1. Average annual birth rates and total number of live briths, by mother's ethnicity in the Republic of Croatia, 1998 - 2008

\begin{tabular}{ccc}
\hline Narodnost & $\begin{array}{c}\text { Prosječna godišnja stopa } \\
\text { nataliteta (na 1000 st.) }\end{array}$ & $\begin{array}{c}\text { Broj živorođenih } \\
\text { prema nar. majke }\end{array}$ \\
\hline hrvatska & 9,79 & 428.290 \\
\hline albanska & 15,85 & 2630 \\
\hline bošnjačka & 4,2 & 958 \\
\hline češka & 6,84 & 791 \\
\hline mađarska & 5,59 & 1020 \\
\hline romska & 45,52 & 4426 \\
\hline slovenska & 2,55 & 369 \\
\hline srpska & 4,29 & 9504 \\
\hline talijanska & 3,58 & 773 \\
\hline ostala & 10,6 & 17.895 \\
\hline
\end{tabular}

Prema tablici 2, narodnosti se statistički značajno razlikuju prema redu rođenja djeteta. To je najuočljivije kod majki albanske, romske, srpske i donekle slovenske narodnosti. Majke albanske i romske narodnosti rodile su više puta od očekivanog broja (tj. imaju troje ili više djece), dok su majke srpske i slovenske nacionalnosti rodile manje puta od očekivanoga, tj. imaju uglavnom po jedno dijete ili dvoje djece. Iako je statistički značajna, povezanost narodnosti majke i reda rođenja djeteta izrazito je mala. 
Tablica 2. Rezultati hi-kvadrat testa za varijable narodnost majke i dosadašnji broj djece, prema podacima o živorođenima $u$ Republici Hrvatskoj od 1998. do 2008.

Table 2. Results of the Chi-square test for the variables mother's ethnicity and current number of children, according to live births data in the Republic of Croatia, 1998 - 2008

Narodnost majke * Dosadašnji broj djece (standardizirani reziduali)

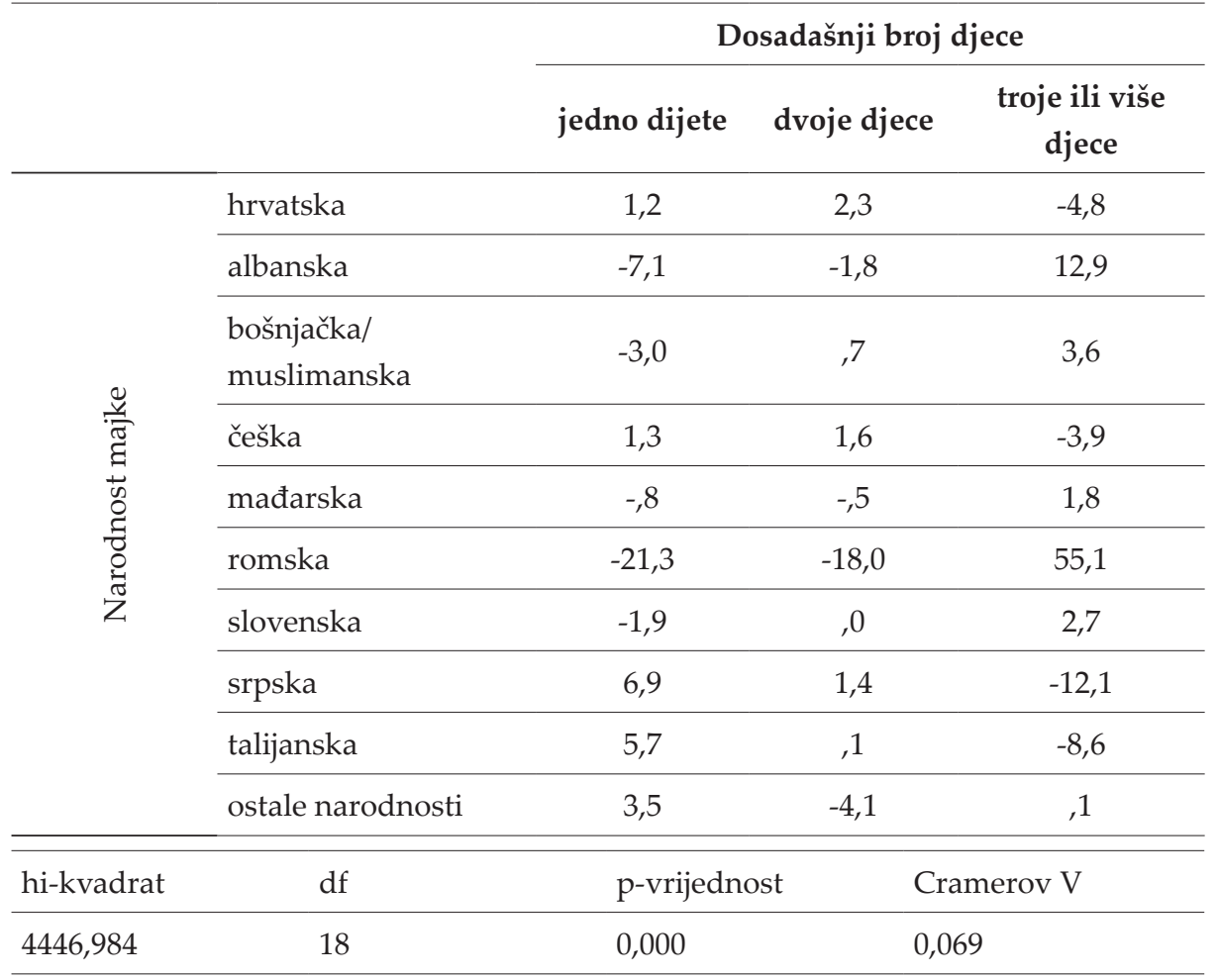


Slika 1. Postotak majki unutar svake narodnosne skupine prema dosadašnjem broju djece, prema podacima o živorođenima u Republici Hrvatskoj od 1998. do 2008.

Figure 1. Percentage of mothers in each ethnic group by current number of children, according to live births data in the Republic of Croatia, $1998-2008$

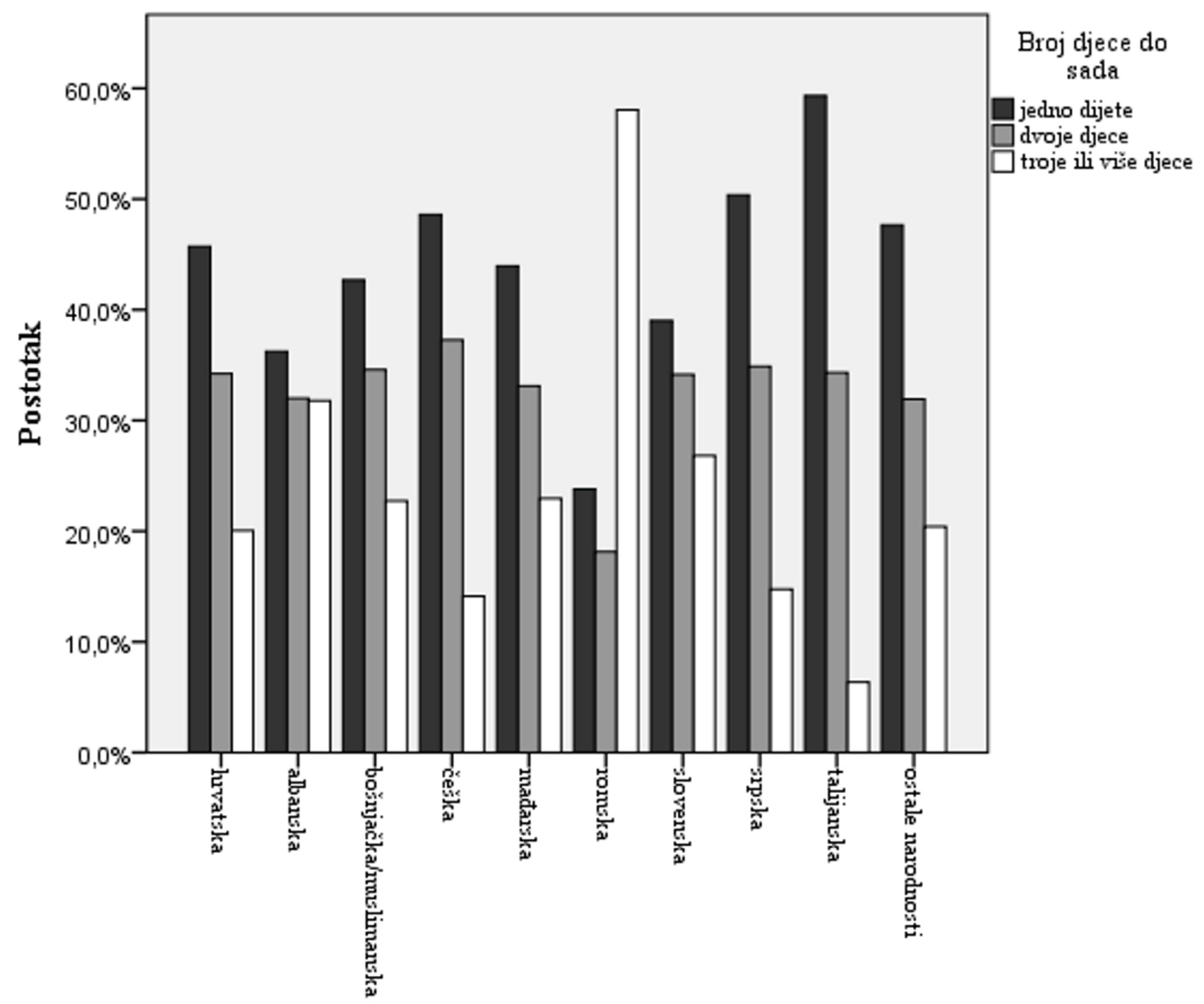

Narodnost majke 
Tablica 3. Rezultati hi-kvadrat testa za varijable narodnost majke i nupcijalitet, prema podacima o živorođenima u Republici Hrvatskoj od 1998. do 2008.

Table 3. Results of the Chi-square test for the variables mother's ethnicity and nuptiality, according to live births data in the Republic of Croatia, $1998-2008$

\begin{tabular}{|c|c|c|c|c|}
\hline \multicolumn{5}{|c|}{ Narodnost majke * Nupcijalitet (standardizirani reziduali) } \\
\hline & & \multicolumn{3}{|c|}{ Nupcijalitet } \\
\hline & & prvi brak & drugi ili više & nije u braku \\
\hline \multirow{10}{*}{ 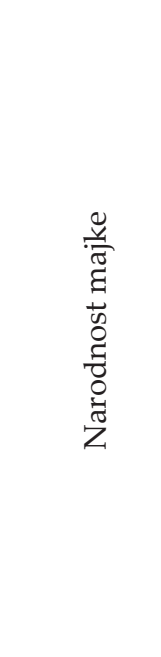 } & hrvatska & 9,9 & $-1,3$ & $-29,0$ \\
\hline & albanska &,- 2 & $-3,0$ & 1,4 \\
\hline & $\begin{array}{l}\text { bošnjačka/ } \\
\text { muslimanska }\end{array}$ & $-7,8$ & 6,7 & 20,9 \\
\hline & češka & 9 & 2,1 & $-3,5$ \\
\hline & mađarska & $-2,1$ & 3,2 & 5,3 \\
\hline & romska & $-47,4$ & $-4,0$ & 142,3 \\
\hline & slovenska &,- 9 &, 5 & 2,7 \\
\hline & srpska & $-6,8$ & 2,1 & 19,4 \\
\hline & talijanska &,- 4 & ,2 & 1,1 \\
\hline & ostale narodnosti & $-18,6$ & 3,5 & 54,1 \\
\hline hi-kvadrat & $\mathrm{df}$ & \multicolumn{2}{|c|}{ p-vrijednost } & Cramerov V \\
\hline 27774,160 & 18 & 0,000 & \multicolumn{2}{|c|}{0,173} \\
\hline
\end{tabular}


Slika 2. Postotak majki unutar svake narodnosne skupine prema varijabli nupcijalitet, prema podacima o živorođenima u Republici Hrvatskoj od 1998. do 2008.

Figure 2. Percentage of mothers in each ethnic group by variable nuptiality, according to live births data in the Republic of Croatia, $1998-2008$

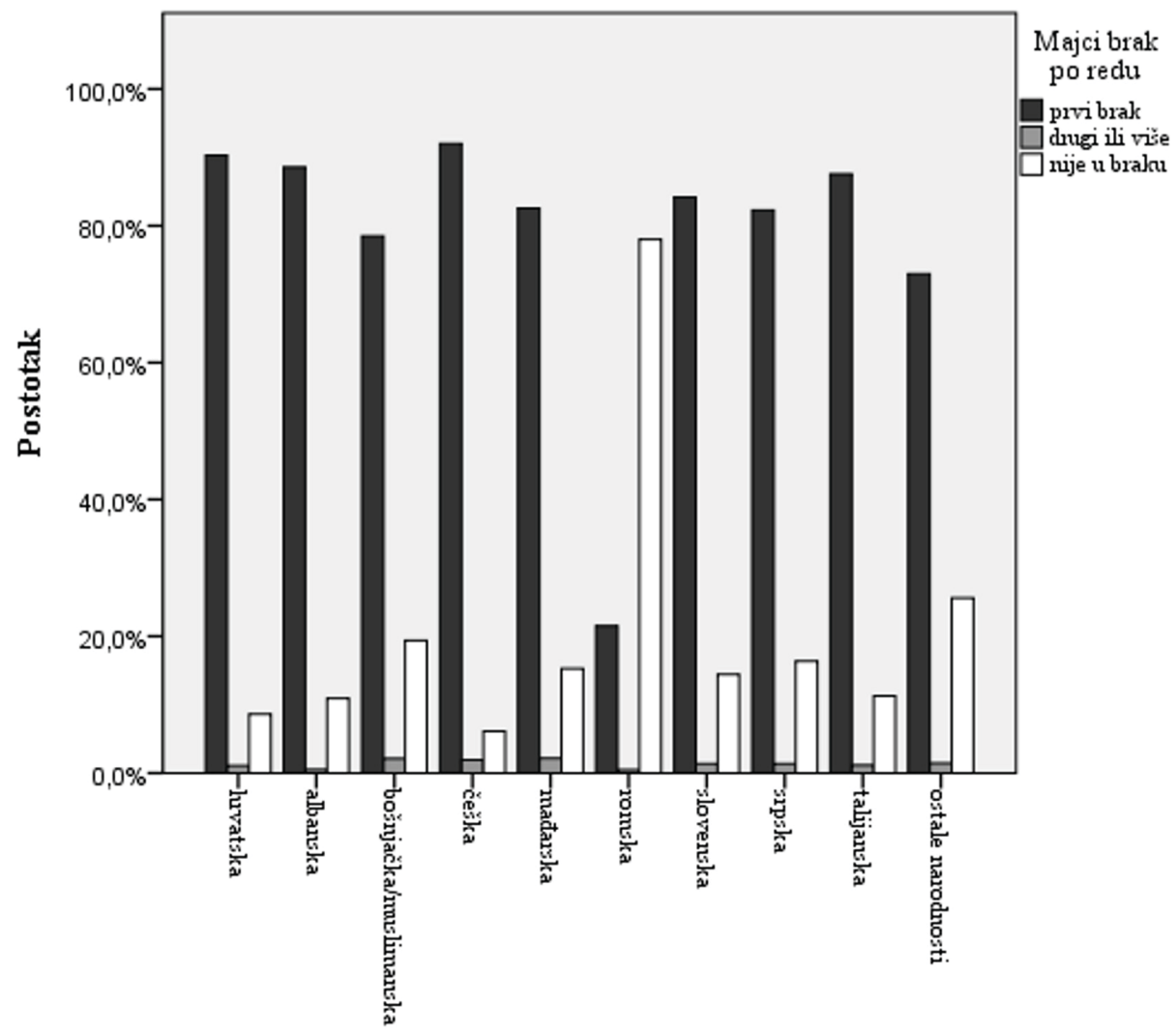

Narodnost majke

Žene različitih narodnosti razlikuju se i po nupcijaliletu (bračnosti). Hrvatice su udane (prvi put) nešto više od očekivanoga, dok među Bošnjakinjama, Romkinjama, ženama ostalih narodnosti i donekle Srpkinjama ima više žena koje nisu u braku. Kod ostalih narodnosti vrijednosti stvarnih frekvencija ne odstupaju znatnije od očekivanih. Iako je povezanost narodnosti majke i nupcijaliteta viša nego istovrsna povezanost s redom rođenja djeteta, još je relativno mala. 
Tablica 4. Rezultati hi-kvadrat testa za varijable narodnost majke i aktivnost majke, prema podacima o živorođenima u Republici Hrvatskoj od 1998. do 2008.

Table 4. Results of the Chi-square test for the variables mother's ethnicity and mother's activity, according to live births data in the Republic of Croatia, 1998 - 2008

\begin{tabular}{|c|c|c|c|c|c|}
\hline \multicolumn{6}{|c|}{ Narodnost majke * Aktivnost majke (standardizirani reziduali) } \\
\hline & & & \multicolumn{3}{|c|}{ Aktivnost majke } \\
\hline & & & $\begin{array}{c}\text { obavlja } \\
\text { zanimanje u } \\
\text { radnom odnosu } \\
\text { ili samostalno }\end{array}$ & $\begin{array}{c}\text { ne obavlja } \\
\text { zanimanje } \\
\text { jer traži prvo } \\
\text { ili ponovno } \\
\text { zaposlenje i sl. } \\
\text { ili je uzdržavana } \\
\text { osoba }\end{array}$ & $\begin{array}{c}\text { osoba s osobnim } \\
\text { prihodom i } \\
\text { osoba na radu } \\
\text { ili boravku u } \\
\text { inozemstvu }\end{array}$ \\
\hline \multirow{10}{*}{ 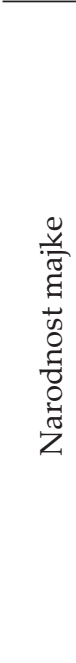 } & hrva & & 11,4 & $-20,9$ &,- 8 \\
\hline & alba & & $-21,7$ & 40,2 & $-1,1$ \\
\hline & $\begin{array}{l}\text { bošr } \\
\text { mus }\end{array}$ & & $-15,2$ & 28,0 & 1,0 \\
\hline & češk & &, 1 & , 0 & $-1,3$ \\
\hline & mac & & $-6,6$ & 12,2 &,- 2 \\
\hline & rom & & $-55,1$ & 100,9 & 7,0 \\
\hline & slov & &,- 8 & 1,4 & 1,3 \\
\hline & srps & & $-8,5$ & 15,9 & $-2,1$ \\
\hline & talij & & 4,7 & $-8,6$ & $-1,3$ \\
\hline & osta & osti & $-8,0$ & 14,4 & 3,4 \\
\hline \multicolumn{2}{|c|}{ hi-kvadrat } & $\mathrm{df}$ & \multicolumn{2}{|c|}{ p-vrijednost } & amerov V \\
\hline \multicolumn{2}{|c|}{17851,472} & 18 & \multicolumn{2}{|c|}{0,000} & 140 \\
\hline
\end{tabular}

Majke različitih narodnosti statistički se značajno razlikuju i po statusu ekonomske aktivnosti. Albanke, Bošnjakinje, Romkinje te donekle Srpkinje i žene ostalih narodnosti češće imaju »neaktivni« ekonomski status, tj. češće pripadaju kategoriji »ne obavlja zanimanje jer traži prvo ili ponovno zapo- 
slenje i sl. ili je uzdržavana osoba«. S druge strane, Hrvatice i Talijanke nešto više sudjeluju u »aktivnoj« kategoriji (»obavlja zanimanje u radnom odnosu ili samostalno«). Unatoč statističkoj značajnosti povezanost narodnosti i aktivnosti majke relativno je mala.

Tablica 5. Rezultati hi-kvadrat testa za varijable narodnost majke i aktivnost oca, prema podacima o živorođenima u Republici Hrvatskoj od 1998. do 2008.

Table 5. Results of the Chi-square test for the variables mother's ethnicity and father's activity, according to live births data in the Republic of Croatia, $1998-2008$

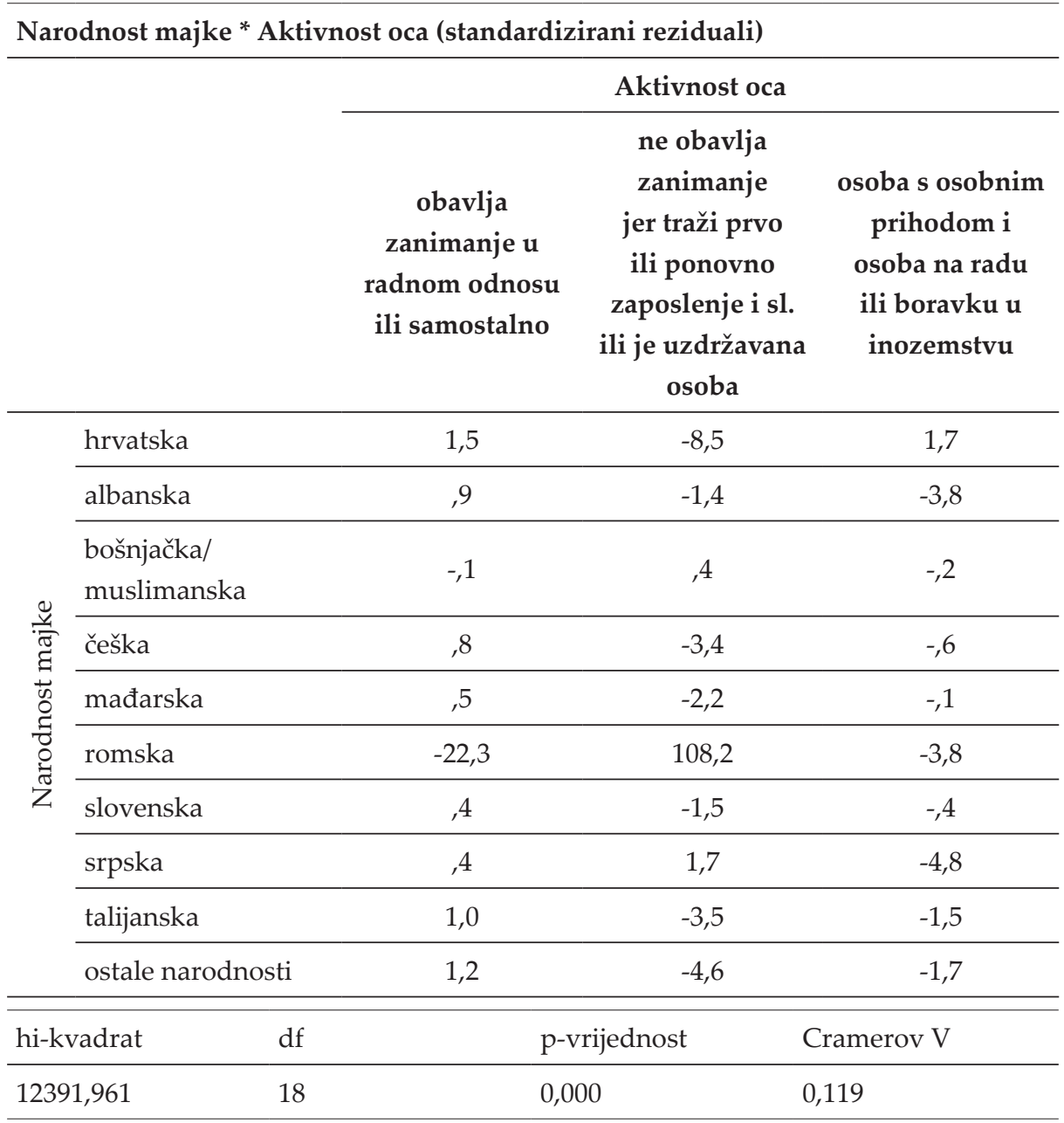


Razlike u aktivnosti oca prema narodnosti majke također su statistički značajne, no nisu tako izražene kao kod aktivnosti žena. Tako je jedina izražena razlika u aktivnosti oca ona kod Roma, koji imaju znatno više »neaktivnih « muškaraca od očekivanoga. Iako statistički značajna, povezanost je narodnosti majke i aktivnosti oca mala.

Tablica 6. Rezultati hi-kvadrat testa za varijable narodnost majke i dob majke pri rađanju djeteta i prosječna dob majke pri rađanju djeteta, prema podacima o živorođenima u Republici Hrvatskoj od 1998. do 2008.

Table 6. Results of the Chi-square test for the variables mother's ethnicity and age at child birth, and average mother's age at child birth, according to live births data in the Republic of Croatia, 1998 2008

\section{Narodnost majke * Dob majke (standardizirani reziduali)}

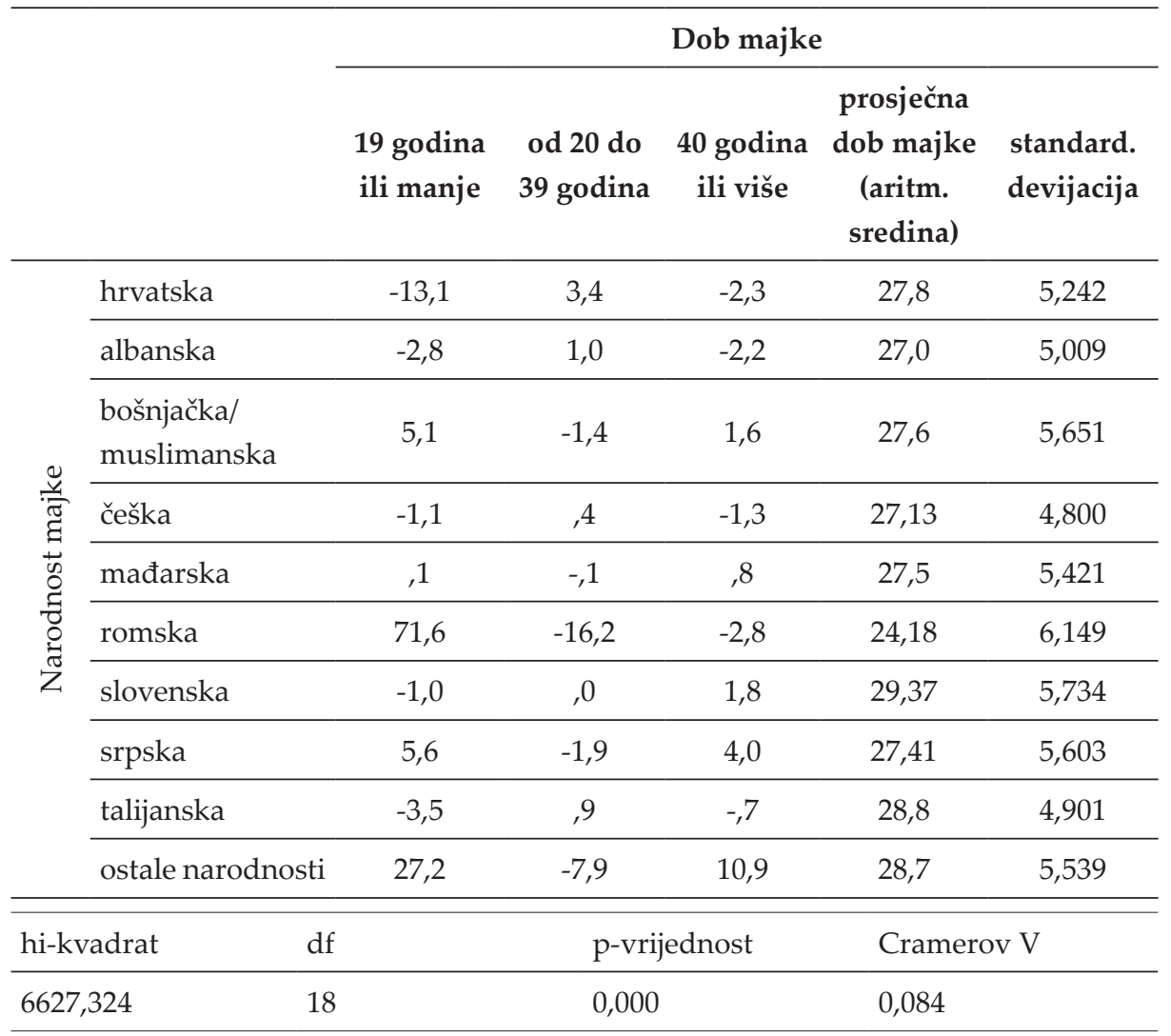


Majke različitih narodnosti razlikuju se i po dobi pri rađanju djeteta. Romske majke i majke ostalih narodnosti nerazmjerno više rađaju mlađe (kategorija »19 godina ili mlađe«), a donekle i bošnjačke i srpske. Zanimljivo je da je kod tih narodnosti, osim romske, uz povećani udio mlađih majki prisutan i ponešto veći udio starijih majki (kategorija »40 godina i više«). S druge strane, hrvatska i talijanska zajednica imaju manje majki u prvoj, najmlađoj kategoriji. Povezanost narodnosti i dobi majke izrazito je mala.

Tablica 7. Rezultati hi-kvadrat testa za varijable narodnost majke, dob oca pri rođenju djeteta i prosječna dob oca pri rođenju djeteta, prema podacima o živorođenima u Republici Hrvatskoj od 1998. do 2008.

Table 7. Results of the Chi-square test for the variables mother's ethnicity and father's age at child birth, and average father's age at child birth, according to live births data in the Republic of Croatia, $1998-2008$

\begin{tabular}{|c|c|c|c|c|c|c|}
\hline \multicolumn{7}{|c|}{ Narodnost majke * Dob oca (standardizirani reziduali) } \\
\hline & & \multicolumn{5}{|c|}{ Dob oca } \\
\hline & & $\begin{array}{l}19 \text { godina } \\
\text { ili manje }\end{array}$ & $\begin{array}{l}\text { od } 20 \text { do } \\
39 \text { godina }\end{array}$ & $\begin{array}{l}40 \text { godina } \\
\text { ili više }\end{array}$ & $\begin{array}{c}\text { prosječna } \\
\text { dob oca } \\
\text { (aritm. } \\
\text { sredina) }\end{array}$ & $\begin{array}{l}\text { standard. } \\
\text { devijacija }\end{array}$ \\
\hline \multirow{10}{*}{ 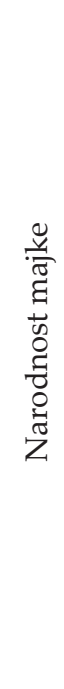 } & hrvatska & $-32,7$ & 7,8 & $-1,6$ & 31,28 & 5,982 \\
\hline & albanska & 1,7 & ,3 & $-2,1$ & 30,67 & 5,923 \\
\hline & $\begin{array}{l}\text { bošnjačka/ } \\
\text { muslimanska }\end{array}$ & 17,4 & $-5,7$ & 5,6 & 31,54 & 6,627 \\
\hline & češka & $-3,4$ & ,9 &,- 3 & 31,14 & 5,896 \\
\hline & mađarska &,- 1 & $-1,0$ & 3,1 & 31,86 & 6,239 \\
\hline & romska & 101,9 & $-18,9$ & $-11,6$ & 26,66 & 6,713 \\
\hline & slovenska & 1 & $-1,4$ & 4,5 & 32,93 & 6,458 \\
\hline & srpska & 2,9 & $-2,2$ & 4,9 & 31,27 & 6,306 \\
\hline & talijanska & $-1,4$ & , 2 & ,2 & 31,54 & 5,751 \\
\hline & $\begin{array}{l}\text { ostale } \\
\text { narodnosti }\end{array}$ & 111,8 & $-27,2$ & 7,6 & 32,58 & 6,552 \\
\hline \multicolumn{2}{|c|}{ hi-kvadrat } & df & \multicolumn{2}{|c|}{ p-vrijednost } & \multicolumn{2}{|c|}{ Cramerov V } \\
\hline \multicolumn{2}{|c|}{25765,868} & 18 & \multicolumn{2}{|c|}{0,000} & \multicolumn{2}{|l|}{0,166} \\
\hline
\end{tabular}


Izrazita prisutnost mlađih očeva uočljiva je kod Roma, Bošnjaka i muškaraca ostalih narodnosti, dok je manje izražena kod Srba. Za razliku od romskih očeva, kod ostale tri navedene kategorije prisutan je i veći broj starijih očeva (kategorija »40 godina i više«). Kod Hrvata ima manje mlađih očeva, većim su dijelom u »srednjoj« kategoriji (»od 20 do 39 godina«). Povezanost narodnosti majke i dobi oca nešto je veća od istovrsne povezanosti s dobi majke, no i dalje relativno mala.

Tablica 8. Rezultati hi-kvadrat testa za varijable narodnost majke i razina obrazovanja majke, prema podacima o živorođenima u Republici Hrvatskoj od 1998. do 2008.

Table 8. Results of the Chi-square test for the variables mother's ethnicity and level of education, according to live births data in the Republic of Croatia, 1998 - 2008

\begin{tabular}{l} 
Narodnost majke * Razina obrazovanja majke (standardizirani reziduali) \\
\hline
\end{tabular}

\begin{tabular}{llll}
\hline \hline hi-kvadrat & df & p-vrijednost & Cramerov V \\
\hline 16265,168 & 18 & 0,000 & 0,132 \\
\hline
\end{tabular}


Slika 3. Postotak majki unutar svake narodnosne skupine prema obrazovanju majke, prema podacima o živorođenima u Republici Hrvatskoj od 1998. do 2008.

Figure 3. Percentage of mothers in each ethnic group by mother's level of education, according to live births data in the Republic of Croatia, $1998-2008$

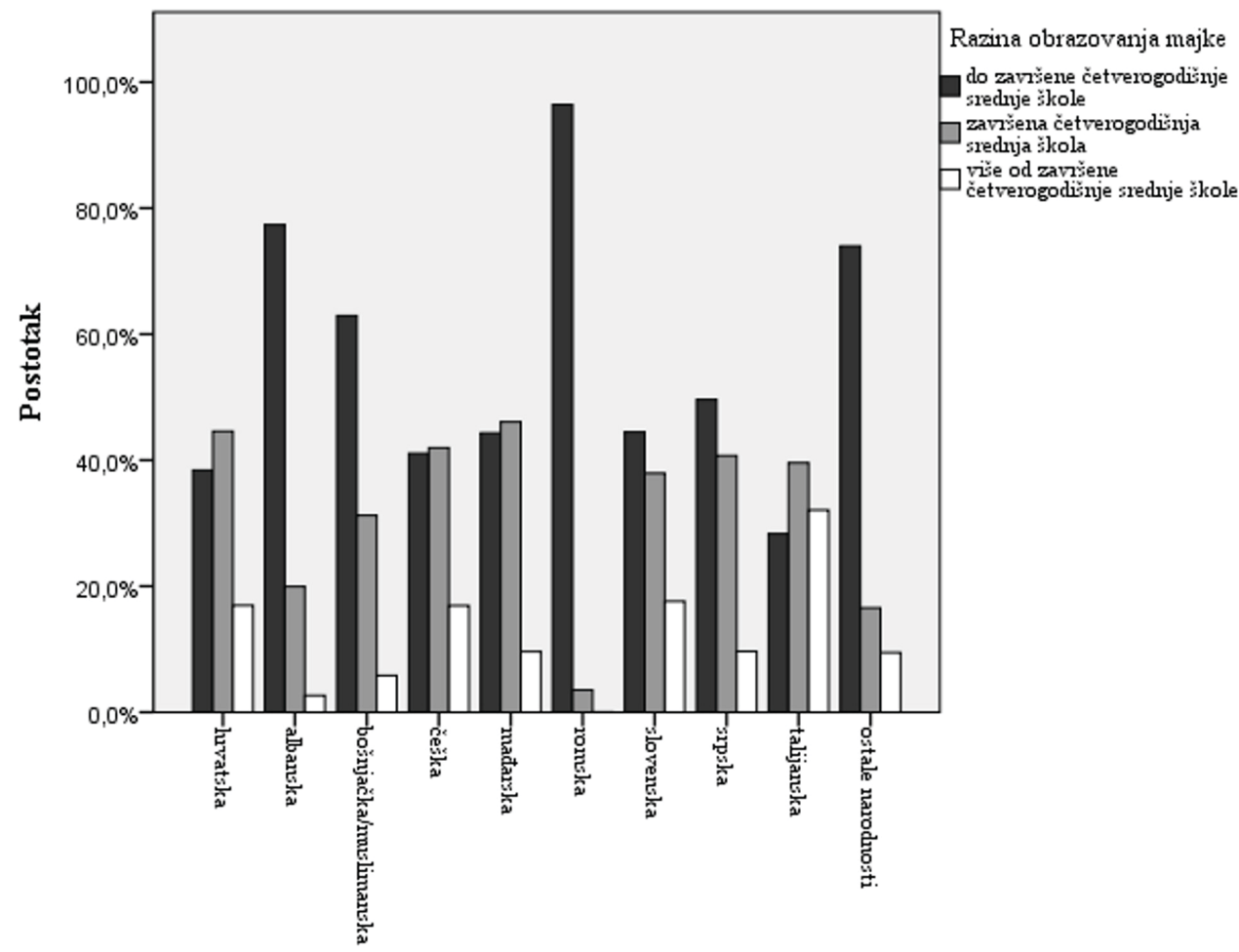

Narodnost majke

Veći broj albanskih, bošnjačkih, donekle srpskih, a posebice romskih i majki ostalih narodnosti ima manje od završene četverogodišnje srednje škole. Boljeg su obrazovnog statusa majke hrvatske i talijanske narodnosti. Povezanost je tih dviju varijabli mala. 
Tablica 9. Rezultati hi-kvadrat testa za varijable narodnost majke i razina obrazovanja oca, prema podacima o živorođenima u Republici Hrvatskoj od 1998. do 2008

Table 9. Results of the Chi-square test for the variables mother's ethnicity and father's level of education, according to live births data in the Republic of Croatia, 1998 - 2008

\begin{tabular}{l} 
Narodnost majke * Razina obrazovanja oca (standardizirani reziduali) \\
\hline
\end{tabular}


Slika 4. Postotak majki unutar svake narodnosne skupine prema obrazovanju oca, prema podacima o živorođenima u Republici Hrvatskoj od 1998. do 2008.

Figure 4. Percentage of mothers in each ethnic group by father's level of education, according to live births data in the Republic of Croatia, $1998-2008$

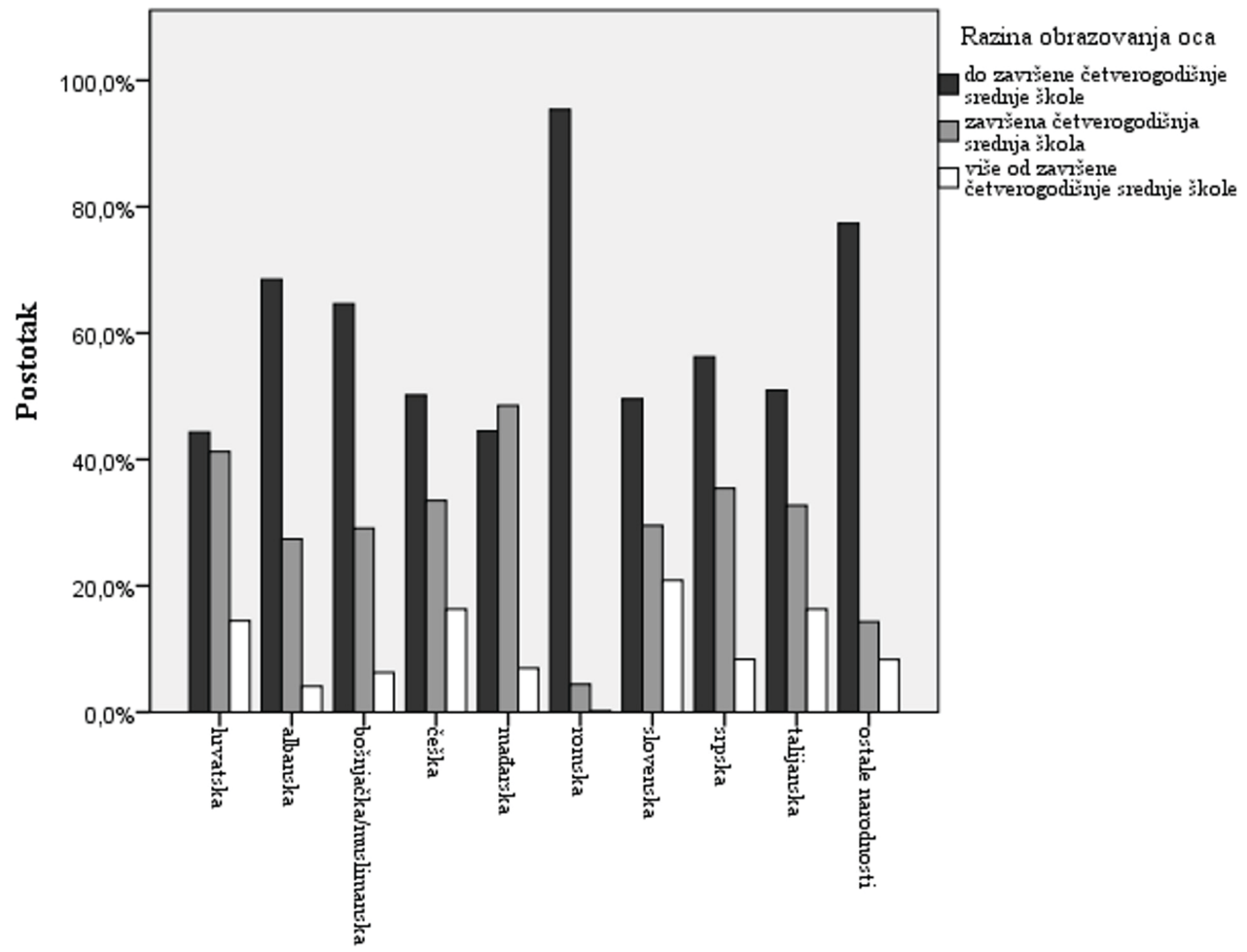

Narodnost majke

Gotovo je identična situacija i kod odnosa narodnosti majke i obrazovanja oca. Kao i u prethodnom primjeru albanski, bošnjački, romski, očevi ostalih narodnosti i donekle srpski očevi lošijeg su obrazovnog statusa, dok su oni hrvatski i talijanski boljega. Povezanost promatranih varijabli i ovdje je mala. 


\section{RASPRAVA}

Rezultati istraživanja upućuju na vrlo veliku varijaciju u natalitetu etničkih skupina u Republici Hrvatskoj od 1998. do 2008., a analiza varijabli red rođenja djeteta, dob majke i oca, obrazovanje majke i oca, ekonomska aktivnost majke i oca, je li dijete rođeno $u$ braku te koji je to majci brak po redu prema narodnosti majke pokazala je statistički značajne, ali relativno male povezanosti parova varijabli. Tako albanske, bošnjačke, romske, žene ostalih narodnosti, a donekle i srpske žene imaju veću šansu da budu neudane, imaju više djece, budu manje ekonomski aktivne, mlađe i manje obrazovane, kao i očevi njihove djece. Uz iznimku bošnjačke i srpske nacionalne manjine te skupine imaju relativno visoki natalitet $\mathrm{u}$ usporedbi $\mathrm{s}$ ostalim skupinama.

Na temelju dobivenih rezultata ne možemo zaključiti da je narodnost majke značajan čimbenik pri objašnjenju varijacije ostalih promatranih varijabli jer je povezanost narodnosti majke i tih varijabli relativno niska. Ipak, navedene razlike mogu upućivati na različitu dinamiku nataliteta kod narodnosnih skupina. Tako visoki natalitet kod romskog stanovništva korespondira s niskim nupcijalitetom i nepovoljnom obrazovno-ekonomskom strukturom obitelji. Romsko se stanovništvo, prema tome, nalazi u stanju prije demografske tranzicije, a to stanje odlikuje visoki natalitet, ali i relativno visoki mortalitet dojenčadi. Te karakteristike romske populacije uočio je Šlezak (2010) u već navedenom istraživanju. Takva demografska dinamika kod Roma ne čudi s obzirom na socijalnu isključenost romskog stanovništva, ali i njihovu geografsku distanciranost (Šlezak, 2009). Albanska etnička skupina pokazuje karakteristike slične romskom stanovništvu, no ipak manje izražene. Relativno visoki natalitet posljedica je najvjerojatnije kulturnovjerske i jezične posebitosti albanske etničke skupine i obrazaca nataliteta u matičnim područjima Albanije i Kosova. Ta je posebitost vidljiva i u činjenici da majke albanske nacionalne manjine najčešće izabiru partnere albanske narodnosti. Prema analiziranim podacima rađanja albanskih majki, otac je bio Albanac u 80,61\% slučajeva, od čega jedino Hrvati imaju veće »slaganje« - $94,81 \%$.

Iako i bošnjačka i srpska narodnosna skupina imaju slične, ali manje izražene socioekonomske obrasce, te dvije skupine imaju relativno niski natalitet. Uz već navedenu činjenicu da narodnost ne objašnjava najbolje varijaciju u socioekonomskom statusu, moguće je da su kod te skupine prisutni i problemi s popisivanjem. Naime u podacima o rođenjima postoji razlika između narodnosti »Bošnjak « i »Musliman«, a od 1998. do 2000. postojala je i dodatna kategorija »Musliman-bošnjak«. S druge strane, u podacima iz 
Popisa stanovništva 2001. dostupan je ukupni broj stanovnika samo za kategoriju »Bošnjak «, dok je kategorija »Musliman« pridružena kategoriji »ostali«. Budući da su pri izračunu hi-kvadrat testova podaci za kategorije »Bošnjak« $\mathrm{i}$ »Musliman « bili spojeni u jednu radi postizanja reprezentativnijeg broja rođenja, moguće je da socioekonomski obrazac za tu kombiniranu kategoriju ne odgovara stopi nataliteta koja je izračunata samo za kategoriju »Bošnjak «. Kod srpske narodnosti upitan je broj ukupnog stanovništva prema popisu stanovništva iz 2001. Ne može se sa sigurnošću reći koliko je od popisanih stanovnika stvarno živjelo u Republici Hrvatskoj i pridonijelo "srpskom « natalitetu, a koliko ih je došlo u RH samo za potrebe popisa. Uz pretpostavku da popis precjenjuje broj stanovnika srpske narodnosti u RH njihov je natalitet podcijenjen.

Činjenica da druge narodnosne skupine (češka, mađarska i slovenska) ne odudaraju od očekivanih vrijednosti, ili u slučaju talijanske nacionalne manjine odudaraju u suprotnom smjeru od albanske, romske, bošnjačke i srpske, vjerojatno se može objasniti povijesnim okolnostima i posebitostima nacionalnih manjina u Hrvatskoj. Navedena istraživanja iz SAD-a i Zapadne Europe koja su utvrdila razlike $\mathrm{u}$ fertilnim karakteristikama manjinskih skupina i domicilnog stanovništva činila su to za skupine nedavnih imigranata ili prve generacije manjinskih stanovnika rođenih $\mathrm{u}$ tim zemljama (Coleman i Dubuc, 2010; Penn i Lambert, 2002; Lindley, Dale i Dex, 2004). Za razliku od njih manjinske su skupine u Hrvatskoj »stare « manjine koje borave na prostorima Hrvatske više stotina godina. Zbog toga su toliko asimilirane u domaće stanovništvo da se postavlja pitanje koliko ih drugi i koliko se oni sami percipiraju nacionalnom manjinom. Potvrda je za to i veliki postotak veza s partnerima drugih nacionalnosti. Majke češke, mađarske, slovenske i talijanske nacionalnosti imaju partnere iste nacionalnosti u 29,58\%, 28,33\%, 0,81\% i 21,35\% slučajeva (po redu). Većina partnera tih majki dolazi iz dominantne, hrvatske etničke skupine, što je u suprotnosti s podacima iz SR Hrvatske, gdje je bračna homogenost prema narodnosti bila jako izražena (Botev, 1994). Ipak podaci iz SR Hrvatske obuhvaćaju sve brakove, a podaci od 1998. do 2008. samo žene koje su rodile, uključujući one koje nisu u braku. U međunarodnom kontekstu većina istraživanih manjina pripada tzv. vidljivim manjinama (Statistics Canada, 2012), tj. osobama koje nisu kavkaskog podrijetla i koje dominantne etničke skupine u Europi i SAD-u najčešće percipiraju kao različite. Navedene četiri nacionalne manjine zasigurno nisu »vidljive manjine«, no u slučaju romske populacije taj se koncept pokazuje znanstveno vrijednim jer je ta nacionalna skupina jedina stvarno segregirana te također i prepoznatljiva prema svojim tjelesnim karakteristikama. 
Najvjerojatnije objašnjenje niskog nataliteta nekih narodnosnih skupina nepovoljna je dobna struktura tog stanovništva, uz veće navedene kulturne razlike. Nažalost, zbog nekih metodoloških ograničenja pri ovom istraživanju nije bilo moguće kontrolirati varijable te samim tim ni postaviti dalekosežne zaključke. Prvo, dostupni su samo podaci o rođenjima, pa na temelju njih nije moguće sa sigurnošću zaključivati o stopama nataliteta. Naime nije poznato koliko žena određene narodnosti uopće nije rodilo, a nisu poznate ni njihove socioekonomske karakteristike. Broj žena koje nisu rodile može se razlikovati između etničkih skupina te tako biti bitni čimbenik nataliteta jer se ukupni broj stanovnika, a samim tim i ukupni broj žena nalaze u nazivniku stope nataliteta.

Druga je poteškoća dvojbena nezavisnost podataka. Pretpostavka hikvadrat testa jest da se svaka opservacija nalazi samo u jednoj ćeliji tablice. Budući da je vrlo vjerojatno da je pojedina žena rodila više puta tijekom promatranog razdoblja, moguće je da se pojavila više puta u istoj ćeliji pojedine tablice. Ta činjenica smanjuje standardne pogreške pri određivanju parametara testa i samim tim povećava vjerojatnost pogreške tipa 1, tj. vjerojatnost prihvaćanja rezultata testa kao statistički značajnoga premda on to zapravo nije. U ovome istraživanju nije bilo moguće identificirati takve opservacije. Zbog toga se nije pristupilo multivarijatnom testiranju log-linearnim ili logističkim modelima, premda bi se tako kontrolirale varijable npr. dobi. Da je dobna struktura narodnosti vjerojatni čimbenik pri objašnjenju njihova različitog nataliteta, potvrđuju i podaci popisa stanovništva iz 2011. Prosječna starost Čeha, Mađara, Srba, Slovenaca i Talijana viša je od hrvatskog prosjeka, dok je ona Roma i Albanaca niža (Popis stanovništva, kućanstava i stanova 2011.,..., 2013). Dodatna je poteškoća veličina uzorka jer je moguće da međuetničke razlike postanu statistički značajne samo zbog velikog broja opservacija premda je stvarna razlika zapravo zanemariva.

Zbog svega navedenoga rezultate ovog istraživanja valja oprezno interpretirati. Iako neke razlike među etničkim skupinama jesu statistički značajne, njihova je stvarna značajnost vrlo malena. Za svako buduće istraživanje bit će nužno imati detaljnije podatke o socioekonomskim kategorijama osoba pojedine narodnosne skupine. Stoga apeliramo prije svega na Državni zavod za statistiku da tablično objavi podatke o demografskim i socioekonomskim karakteristikama osoba pojedinih etničkih skupina. Oni nisu od interesa samo znanstvenicima nego i široj javnosti, jer moguće razlike među etničkim skupinama i njihovi uzroci mogu biti temelj za kvalitetniju demografsku i socijalnu politiku. 


\section{LITERATURA}

Akrap, A. (2008). Demografski kontekst raspada SFR Jugoslavije. PILAR - časopis za društvene i humanističke studije, 5 (1): 11-58.

Botev, N. (1994). Where East meets West: Ethnic intermarriage in the former Yugoslavia, 1962 to 1989, American Sociological Review, 59 (3): 461-480.

Coleman, D. A. i Dubuc, S. (2010). The fertility of ethnic minorities in the UK, 1960s-2006, Population Studies, 64 (1): 19-41, doi: http://dx.doi.org/10.1080/00324720903391201.

Forste, R. i Tienda, M. (1996). What's behind racial and ethnic fertility differentials?, Population and Development Review, 22 (1996): 109-133.

Gelo, J. (1999). Ratni učinci na promjene demografskih struktura u Hrvatskoj, Društvena istraživanja, 8 (5-6): 735-749.

Klemenčič, M. (2006). The Effects of the Dissolution of Yugoslavia on Minority Rights: the Italian Minority in Post-Yugoslav Slovenia and Croatia, u: S. G. Ellis, G. Hálfdanarson i A. K. Isaacs. (ur.). Citizenship in historical perspective. Pisa: Edizioni Plus, 333-347.

Lindley, J., Dale, A. i Dex, S. (2004). Ethnic differences in women's demographic, family characteristics and economic activity profiles, 1992 to 2002, Labour Market Trends, 112 (4): 153-165.

Penn, R. i Lambert, P. (2002). Attitudes towards ideal family size of different ethnic/ nationality groups in Great Britain, France and Germany, Population Trends, 108: 49-58.

Popis stanovništva, kućanstava i stanova 2011., Stanovništvo prema državljanstvu, narodnosti, vjeri i materinskom jeziku, Statistička izvješća, br. 1469, Državni zavod za statistiku, Zagreb, 2013.

Prirodno kretanje stanovništva u Republici Hrvatskoj 2008., Priopćenja 7.1.1. 2009., Državni zavod za statistiku, Zagreb.

Statistics Canada (2012). Classification of visible minority, http://www.statcan.gc.ca/ concepts/definitions/minority01-minorite01a-eng.htm (16. 03. 2013.).

Šlezak, H. (2009). Prostorna segregacija romskog stanovništva u Međimurskoj županiji, Hrvatski geografski glasnik, 71 (2): 65-81.

Šlezak, H. (2010). Prirodno kretanje romskog stanovništva u Međimurskoj županiji slučaj romskog naselja Kuršanec, Hrvatski geografski glasnik, 72 (2): 77-99.

Šućur, Z. (2009). Pokazatelji ekonomske isključenosti među Hrvatima i nacionalnim manjinama u Republici Hrvatskoj, Revija za socijalnu politiku, 16 (2): 115-140.

Yang, Y. i Morgan, S. P. (2003). How big are educational and racial fertility differentials in the U.S.?, Social Biology, 50 (3-4): 167-187, doi: http://dx.doi.org/10.1080/19485565 .2003.9989070.

Živić, D. (1998). Razvoj etničke strukture Istočne Slavonije u drugoj polovici 20. stoljeća, Hroatski geografski glasnik, 60: 75-103.

Živić, D. i Pokos, N. (2004). Demografski gubitci tijekom Domovinskog rata kao odrednica depopulacije Hrvatske (1991. - 2001.), Društvena istraživanja, 4-5 (72-73): 727-750. 


\section{Birth Rates of Ethnic Groups in Croatia from 1998 to 2008}

\section{Dario Pavić}

\section{SUMMARY}

Belonging to an ethnic group can affect both socio-economic status and birth-rate (fertility) of the individual. Thus women of minority ethnic groups usually have a relatively high birth-rate, and they are more often single mothers, have lower education and generally lower socio-economic status. Although numerous international researches confirmed the differences in birth rates between ethnic groups, the relationship between ethnicity and birth rates has almost not been investigated in Croatia. This research analyzed the fertility rates of ethnic groups in the Republic of Croatia as well as the relationship between mother's ethnicity and socio-economic variables: age at birth, education, economic activity, nuptiality and birth order. The birth data from DEM-1 forms were used for years 1998 to 2008 as well as the data from the 2001 Census. The links between the mother's ethnicity and all of the socioeconomic variables was established although the magnitude of this correlation was small. Also, there were significant differences in the fertility rates of ethnic groups. The women of Albanian, Bosniak, Romani and other ethnicities, and to some degree Serbian women as well, had lower socio-economic status while the Romani and Albanian women had high fertility. However, it is not possible to establish a clear relationship between ethnicity and fertility owing to methodological difficulties and the way of keeping vital statistics. The inclusion of the variable ethnicity and the presentation of socio-economic variables according to mother's ethnicity in the official statistical publications would facilitate future research and enable to create a more efficient demographic and social policy.

KEY WORDS: birth rate, ethnicity, ethnic groups, Croatia 